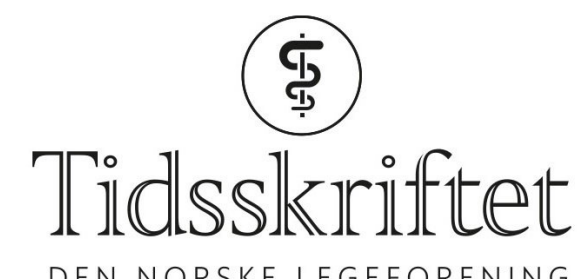

DEN NORSKE LEGEFORENING

\title{
Tanker i natten
}

LEGELIVET

\section{ALEXANDER WAHL}

E-post:alexanderwahl32@gmail.com

Alexander Wahl (f. 1963) er veileder og spesialist i allmennmedisin og arbeider ved Kurbadet legesenter. Han er også redaktør for primærhelsetjenesten i Helsebiblioteket.

Har du ligget våken en natt og bekymret deg over en pasient eller to? Jeg har ingen statistikk på det, men du er neppe alene.

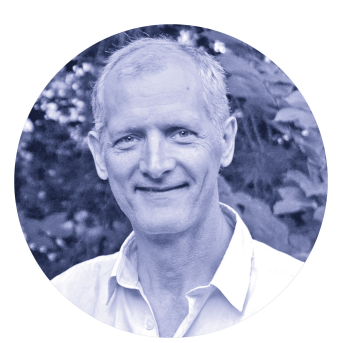

Foto: Privat

Kl o424 En urolig drøm vekker meg, jeg ligger i halvsøvne og kjenner tyngden av min egen kropp sammen med tyngden av ansvar. Pasient nummer én som nesten ble kvalt av sin samboer, møtte ikke opp på konsultasjonen som vi hadde avtalt. Pasient nummer to, med hjertesvikt og ødemer opp til lårene, ville ikke legges inn. Til tross for farlig lavt blodtrykk fikk hun forsiktige doser vanndrivende - jeg håper det går bra. Folk dør, faktisk. De fleste etter et langt liv, men noen dør i livets vår - stjerner lyser hvite.

Noen stjerneløse netter myldrer det på med usikkerhet. Det er en ære å motta pasientens tillit, men også en tyngsel når livet i realiteten er et usikkert prosjekt - kanskje aller mest hvis noen nær deg er alvorlig syk - eller når noen i din omgangskrets dør. Det er vanskelig å forsone seg med døden. Det er hardt, men uomgjengelig.

Av og til møter vi døende som har forsonet seg med utgangen på livet. En fred og en direkte ærlighet står og ser på deg. Slike møter gjør at du må gå i deg selv. Tanker om egen helse, egen kropp i livets spinnende hjul blander seg inn. Hvordan går det nå med egenomsorgen? Er den i riktig balanse?

Om den siste tid sa Marcus Aurelius: «Beveg deg så gjennom denne lille lommen av tid i harmoni med naturen og avslutt reisen din i tilfredshet, akkurat som en oliven faller av greinen når den er moden og velsigner naturen som skapte den og takker treet som lot den gro.»

Kl 0525 er det fortsatt mørkt, men perspektivet utvider seg. Jeg er blitt til et vi, et oss. Flere leger ligger i sine senger med sine nattanker, sine svarte perler som binder oss sammen til et kjede av omsorg og medfølelse for menneskene som berører oss. Det er en vakker tanke at 
vi utgjør et fellesskap. Og med de daglige påminnelsene om visse pasienters elendighet og vår felles absolutte endelighet gir det oss kraft til å glede oss over det vi har. Gravlunden er der, men vi er her-levende - med rikelig anledning til å observere det som vokser, og se det som er vakkert.

Og hva er det som er vakkert i legegjerningen? Å hjelpe andre er et nobelt prosjekt, det gir øyeblikkelig tilfredsstillelse og grunnleggende ro i sin meningsfylde. Legen kan møte et menneske for første gang og oppleve at pasienten åpner seg, forteller hemmeligheter, forteller ærlig om eksistensielle ting. «Nå kaster jeg bort tiden din», kan de si i skam over egen utilstrekkelighet. «Nei», kan vi protestere. «Det du har fortalt er viktig, du har vært modig og vist meg tillit, og takk for det.» Det finnes så mange andre yrker fulle av fraser og skuespill - vi slipper overfladisk ørkenvandring og repeterende automatismer hvis vi tør og tar oss tid til samtalen. Men selvfølgelig skal vi ikke gjøre det hele tiden, vi må prioritere de mest trengende og noenlunde holde tiden.

Kl o626 ringer vekkerklokken. Dagen begynner, og jeg føler meg litt lemster og søvnfattig. Men timeboken er full, så jeg står opp på autopilot. Etter frokost og en god kopp kaffe står solen opp i midt indre. Jeg bestemmer meg for å være frisk og ved friskt mot. I dag skal jeg konsentrere meg om å være til stede så mye som jeg kan.

Mange av de legene som lå våkne i natt, skal i dag dra forsiktig i et barneøre for å kikke inn mot et trommeskinn som spent tar imot sang og musikk og er fremtid, de skal lytte på et hjerte som slår helt av seg selv i livets store kretsløp, de skal holde et hode i sine hender, som dikteren sier, men i tillegg snurre svimmelheten ut av livene deres, halleluja - det er så gøy med Epleys manøver. Og så skal de huske på å få noen til å le.

Ha en god dag på jobben.

Publisert: 8. mai 2018. Tidsskr Nor Legeforen. DOI:10.4045/tidsskr.18.oo68

(C) Tidsskrift for Den norske legeforening 2020. Lastet ned fra tidsskriftet.no 